Scientific Paper

\title{
Evaluation of effective dose and entrance skin dose in digital radiology
}

\author{
Khatereh SHAmsi ${ }^{1}$, Ali SHABESTANI MonfARED ${ }^{2,3, a}$, Mohammad Reza DeEVBAND ${ }^{4}$, Behzad MoHSENZAdeH ${ }^{4}$, \\ Mahdi GHORBANI ${ }^{4}$, Kourosh EBRAHIMNEJAD GORJI ${ }^{2}$, Fatemeh NIKSIRAT ${ }^{2}$ \\ ${ }^{I}$ Student Research Committee, Babol University of Medical Sciences, Babol, Iran \\ ${ }^{2}$ Department of Medical Physics, Radiobiology and Radiation Protection, School of Medicine, Babol University of Medical \\ Sciences, Babol, Iran \\ ${ }^{3}$ Cancer Research Center, Health Research Institute, Babol University of Medical Sciences, Babol, Iran \\ ${ }^{4}$ Biomedical Engineering and Medical Physics Department, School of Medicine, Shahid Beheshti University of Medical \\ Sciences, Tehran, Iran \\ ${ }^{a}$ E-mail address: monfared_ali@yahoo.com
}

(received 15 February 2020; revised 4 April 2020; accepted 27 April 2020)

\begin{abstract}
Background: Ionizing radiation has an indispensable role in diagnostic radiology and clinical treatments. Apparently, medical exposure in diagnostic radiology pertains to be the preeminent man-made source of radiation.

Objective: The aim of the present scientific study is to calculate the Entrance Surface Dose (ESD) and Effective Dose (ED) in digital radiography in Mazandaran province.

Materials and methods: The study was performed on 3600 patients in digital X-ray rooms 15 hospitals and the required data were collected from two age groups (10>15 years and adults) in each projection. Based on the results of this study, ESD and ED were calculated for skull (PA), skull (lateral), cervical spine (AP), cervical spine (lateral), chest (PA), chest (lateral), abdomen (AP), lumbar spine (AP), lumbar spine (lateral), pelvis (AP), thoracic spine (AP) and thoracic spine (lateral) examinations. It was calculated using PCXMC software (version 2.0).

Results: In this study, mean ESDs for the 10-15 year group varied from $0.97 \pm 0.21 \mathrm{mGy}$ to $3.62 \pm 1.38 \mathrm{mGy}$ for chest (PA) and lumbar spine (lateral), respectively. For the adult group varied from $1.05 \pm 0.31$ to $3.85 \pm 1.44$ for cervical spine (AP) and lumbar spine (lateral), respectively. And also ED value was from in the range of $10.40 \mu \mathrm{Sv}$ to $378.46 \mu \mathrm{Sv}$ for skull (PA) 10-15 year group and abdomen adults, respectively

Conclusion: This survey revealed a significant variation in the radiation dose of digital radiology examinations among hospitals in Mazandaran province. Application of a dose reference level (DRL) could be an optimization procedure for reducing the patient's dose in Mazandaran province.
\end{abstract}

Key words: diagnostic radiology; patient dose; dosimetry; dose reference level; entrance surface dose; effective dose.

\section{Introduction}

Humans have always been exposed to two types of radiation, the first of which involves environmental radiation, and the second artificial radiation [1]. Since the discovery of X-rays in 1895 , the process of diagnosing the disease has greatly improved and today, X-ray examinations are widely used in all medical centers around the world, but despite its many advantages in treatment and patient care can pose risks to patients if they do not comply with the principles of protection [2].

As more X-ray machines are developed and more complex examinations are performed, the radiation dose of patients has also increased. Most people are exposed to X-rays from artificial human sources, due to the inevitability of X-rays and its pervasiveness among the people [3]. Radiological procedures, such as simple films or digital equipment, make up $48 \%$ of all diagnostic radiology examinations [4].

The diagnostic radiographic examination of patients, which has the largest contribution to the use of ionizing radiation in medicine, has been the focus of research on dose reduction techniques in diagnostic radiology and has always been a primary focus of research in the field of protection and safety, especially for patients [5].

Optimization and dose reduction should be performed without reducing or losing the necessary diagnostic information. Optimization of protection in diagnostic radiology does not merely mean a reduction of the patient's dose, and more importantly, the obtained image should contain appropriate diagnostic information [6]. 
Entrance Skin Dose (ESD) is an important parameter in evaluating the dose received by a patient in radiography. The European Union has identified this amount in the hope of optimizing the patient's dose as a diagnostic reference. Effective Dose (ED) is the best value for assessing radiation risks for patients. The most important advantage of using ED is that this parameter measures the absorbed doses and the relative radiation of the irradiated organs in patients, and better assess the patient risk $[7,8]$.

In this study, ED and ESD quantities, which are common quantities for routine dose monitoring in conventional radiographic examinations, were used in routine diagnostic radiology examinations $[9,10]$.

All the x-ray machine used in this study were digital. With the increasing and widespread use of digital radiography and the emergence of digital systems, demands for radiology imaging have grown [13]. Additionally also the transition of analog to digital has increased the patient's dose due to a significant increase in the wide dynamic range. A wide dynamic range makes it possible to elevate the radiation conditions without any detrimental effects on the quality of the images. However, insufficient training of the technicians has aroused some problems in this field [14].

The purpose of this study is to measure ESD and ED from 15 radiology centers of public hospitals in Mazandaran province (Iran) for 12 common digital radiographic examinations including skull (PA), skull (lateral), cervical spine (AP), cervical spine (lateral), thoracic (AP), thoracic (lateral), chest spine (PA), chest spine (lateral), lumbar spine (AP), lumbar spine (lateral), abdomen (AP), and pelvis (AP).To the beast of our knowledge, this is the first study done on the calculation of the ED and ESD in digital radiology in Mazandaran province.

\section{Materials and methods}

\section{Data collection method}

In this study, 15 radiography rooms in 15 hospitals in Mazandaran province (Iran) were selected. The information of 12 common digital radiography examinations including skull (PA), skull (lateral), cervical spine (AP), cervical spine (lateral), chest (PA), chest (lateral), abdomen (AP), lumbar spine (AP), lumbar spine (lateral), pelvis (AP), thoracic spine (AP) and thoracic spine (lateral) examinations which were performed in each radiography room was recorded for 10 to 15 years old patients and adult patients. The total number of patients studied in this study was 1800 for the age group of 1015 years and 1800 for the adults. First, information about radiation parameters $(\mathrm{kVp}, \mathrm{mAs})$, geometric parameters including Focus to Skin Distance (FSD), and Focus to Detector Distance (FDD) used in the radiographic examination was recorded. On the other hand, there was no significant difference in body weight and body mass index of patients referring to different centers, which is due to the selection of patients for the 10 to 15 years group with the mean weight between 40 to $60 \mathrm{~kg}$ and the age group adult 60 to $80 \mathrm{~kg}$. Conspicuously, the distribution of the experimental groups was categorized according to age, sex, weight and height, and the number of patients who participated in each age group, and the information are presented in Table 1. Distinctly, the number of patients who underwent each X-ray examination is presented in Table 2, according to their gender. In Table 3 the FFD and exposure settings (X-ray tube voltage $(\mathrm{kVp})$, tube current-time product (mAs), and radiation field size) associated with each $\mathrm{X}$-ray examination are presented.

\section{Measurements of the X-Ray tube output}

For measurement of outputs, a dosimetry kit includes a flat solid-state dosimeter were used (Barracuda X-ray Analyzer, RTI Electronics, Sweden) was used. Calibration of the detector was performed in a Secondary Standard Dosimetry Laboratory (SSDL). This dosimeter was calibrated to measure air kerma in the energy range of 40 to $150 \mathrm{kVp}$ to measure mAs, time, dose rate, (Half Value Layer) HVL, and $\mathrm{kVp}$ parameters. After connecting to the electrometer, a low-scattering material (a wide cardboard plate) was placed on the central axis of the radiation beam at a distance of $100 \mathrm{~cm}$ from the focal points, of the X-rays. Then, the size of the radiation field on the detector was set as a $15 \times 15 \mathrm{~cm}$ field to minimize the effect of the scattered radiation on the detector. In this case, a constant $\mathrm{mA}$ of $10 \mathrm{mAs}$ and tube voltages of $40-110 \mathrm{kVp}$ were set and the dose was recorded by the dosimeter [11].

Table 1. Number of patients in age groups and patient body characteristics (age, height, and weight) of each sex.

\begin{tabular}{ccccccccc}
\hline \hline \multirow{2}{*}{ Age Group } & \multicolumn{2}{c}{ Weight $(\mathbf{k g})$} & & \multicolumn{2}{c}{ Height $(\mathbf{c m})$} & \multirow{2}{*}{ Female } & \multirow{2}{*}{ Male } & \multirow{2}{*}{ Total } \\
\cline { 2 - 3 } & Mean & Range & & Mean & Range & & & \\
\hline $10-15$ years & 49.70 & $29.5-70$ & & 152.50 & $134-177$ & 983 & 817 & 1800 \\
Adult & 76.60 & $58-83$ & & 171.20 & $145-192$ & 803 & 997 & 1800 \\
Total & & & & & 1786 & 1814 & 3600 \\
\hline \hline
\end{tabular}

Table 2. Sex distribution of the studied groups in each examination

\begin{tabular}{cccc}
\hline \hline X-ray examination & Female & Male & Total \\
\hline $\begin{array}{c}\text { Skull (PA) } \\
\text { Skull (lateral) }\end{array}$ & 90 & 85 & 175 \\
$\begin{array}{c}\text { Cervical spine (AP) } \\
\text { Cervical spine (lateral) }\end{array}$ & 154 & 113 & 267 \\
Chest (PA) & 247 & 308 & 555 \\
Chest (lateral) & 165 & 153 & 318 \\
Thoracic spine (AP) & 251 & 244 & 495 \\
Thoracic spine (lateral) & & & \\
Lumbar spine (AP) & 283 & 290 & 573 \\
Lumbar spine (lateral ) & & 304 & 550 \\
Pelvis (AP) & 246 & 317 & 667 \\
Abdomen (AP) & 350 & 1814 & 3600 \\
\hline Total & 1786 & & \\
\hline \hline
\end{tabular}


Table 3. Summary of the patient attributes and applied exposure parameters, including mean (minimum-maximum) values

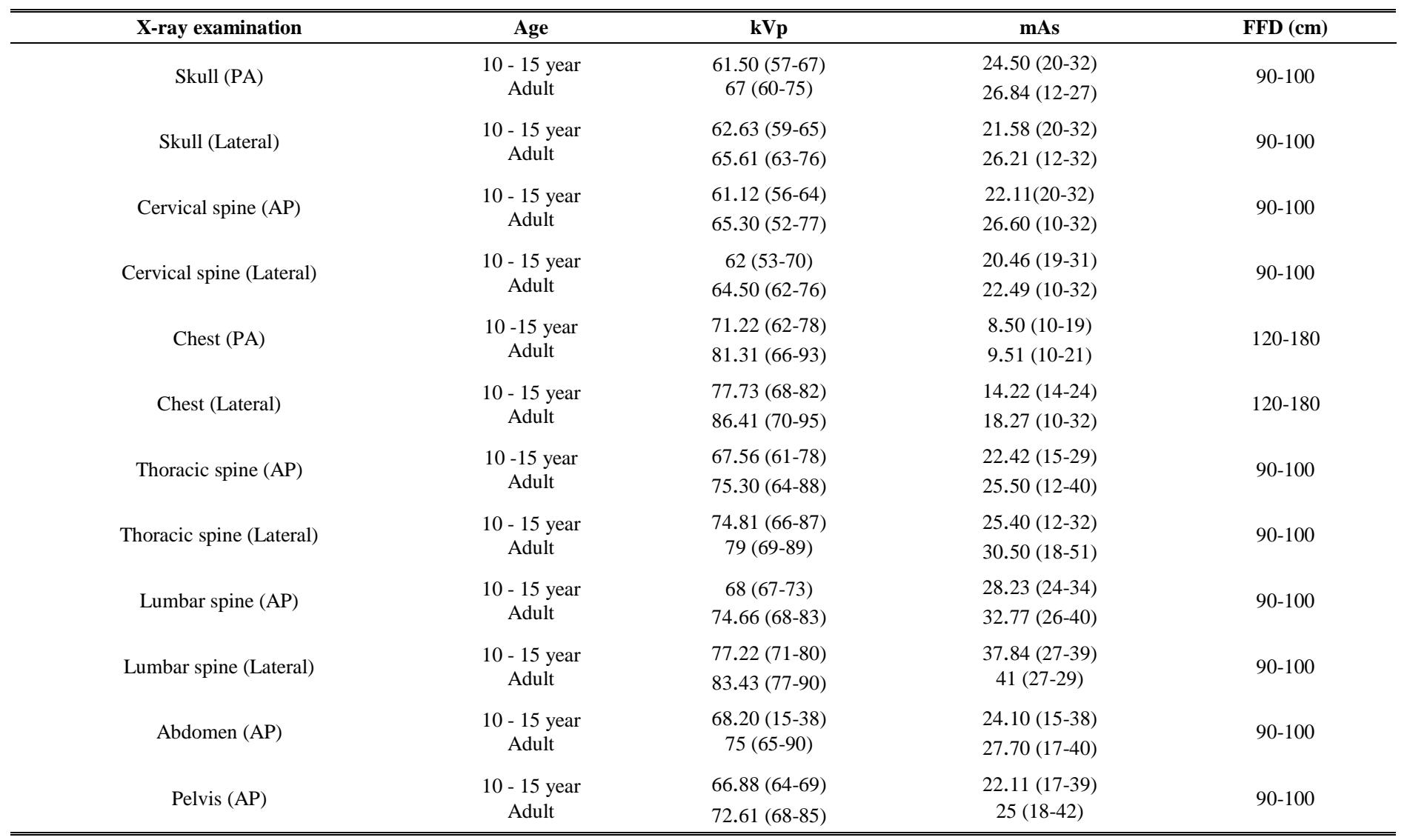

\section{ESAK calculation}

Finally, the Entrance Surface Air Kerma (ESAK) value was calculated from the kerma value obtained from the Back Scatter Factor (BSF). The value of BSF, from by the European Commission report is between 1.2 and 1.4. This coefficient varied from 1.28 to 1.37 in the present study [10,11].

$\mathrm{ESAK}=\mathrm{D}_{\text {air }} \times \mathrm{BSF} \times(\mathrm{FDD} / \mathrm{FSD})^{2}$

Eq. 1

$\mathrm{D}_{\text {air }}$ is the reading value of the dosimeter in (mGy), BSF is backscatter factor which was ranging 1.28 to 1.37 in this study, the distance of the focal spot to a detector is referred to as FDD, and FSD is the distance of $x$-ray focal spot to the patient body $[10,12]$.

\section{Entrance Skin Dose (ESD) calculation}

For the calculation of ESD, ESAK was multiplied to a mass energy absorption coefficient which is equal to 1.06 for tissue and air ( this ratio is approximately 1.06 in digital radiology in $110 \mathrm{kvp}$, with $\pm 1 \%$ error) [10].

$\mathrm{ESD}=\mathrm{ESAK} \cdot 1.06$

Eq. 2 [11]

\section{Effective Dose (ED) calculation}

In this study used PCXMC software (version 2) was used to obtain organ doses. PCXMC software was developed by the Finnish Nuclear Safety and Radiation Center and is based on Monte Carlo calculations. In this software information such as height, weight, peak voltage and film distance to the tube, ESAK value is recorded. The results of ESAK and ESD and patient data were analyzed by PCXMC software and the ED was extracted from the software. Based on these calculations, ED values for the current diagnostic digital radiographs were determined.

\section{Data analysis}

Conspicuously, the distribution of the experimental groups was categorized according to age, sex, mean of weight and height, and the number of patients who participated in each age group. Obviously, the mean value, percentage, error variation coefficient, standard deviation, and minimum and maximum values were calculated by statistical package for the social sciences (SPSS) software version 16.0.

\section{Results}

Table 4 shows the statistical distribution of the average ESD in 15 radiography rooms for the 12 radiographic procedures. The Statistical distributions for all radiography examinations were obtained. In Table 5 the summary of minimum, maximum, the ratio of maximum and minimum, and average dose (mGy) for each X-ray examination is presented. Distribution of means ESD for each $\mathrm{x}$-ray examination is presented in Table 5. Means of patient's doses ranged from $0.97 \mathrm{mGy}$ for the cervical spine (AP) in the $10-15$ year group to $3.85 \mathrm{mGy}$ for 
the lumbar spine (lateral) for the adults. The ESD values for 12 digital radiography examinations in this study were compared with some international ESD values in Table 6. Additionally the comparison of the data obtained in this study to the results of the similar investigations conducted in Iran and other countries is shown in Table 6. EDs calculated using PCXMC software for each digital examination are listed in Table 7.

Table 4. Average ESD (mGy) in 15 rooms for the 12 radiographic examinations for 2 age groups under study irrespective of sex.

\begin{tabular}{|c|c|c|c|c|c|c|c|c|c|c|c|c|}
\hline & $\begin{array}{l}\underset{a}{e} \\
\bar{\Xi} \\
\frac{1}{\sqrt[a]{2}}\end{array}$ & 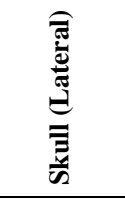 & 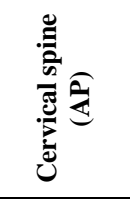 & 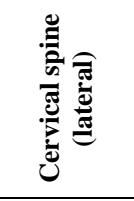 & 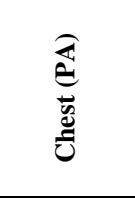 & 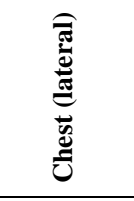 & 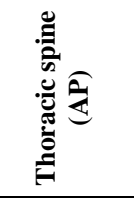 & 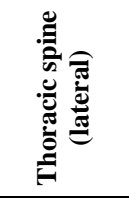 & 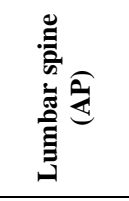 & 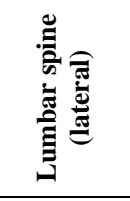 & 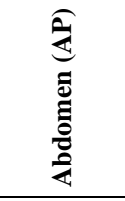 & 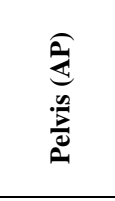 \\
\hline 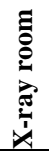 & 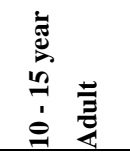 & 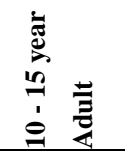 & 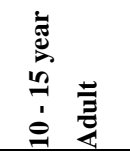 & 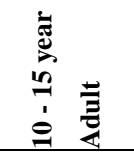 & 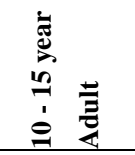 & 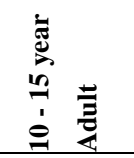 & 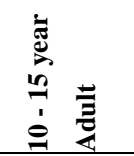 & 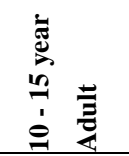 & 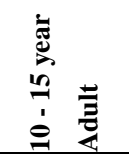 & 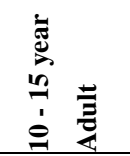 & 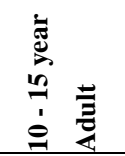 & 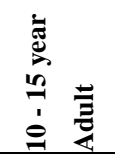 \\
\hline 1 & 0.891 .15 & 0.761 .49 & 0.891 .53 & 0.961 .03 & 0.790 .59 & 1.311 .22 & 1.331 .51 & 2.112 .63 & 1.792 .27 & 2.933 .78 & 1.482 .61 & 1.491 .71 \\
\hline 2 & $\begin{array}{lll}0.51 & 0.52\end{array}$ & $\begin{array}{lll}0.71 & 0.54\end{array}$ & 0.650 .49 & 0.730 .69 & 0.680 .58 & 1.191 .11 & 1.231 .50 & 1.561 .93 & 1.731 .86 & 2.782 .99 & 1.201 .49 & 1.241 .39 \\
\hline 3 & 0.971 .51 & 0.81 .05 & 0.930 .82 & 1.121 .31 & 1.111 .62 & 1.351 .18 & 1.381 .68 & 2.112 .59 & 2.311 .89 & 3.493 .12 & 2.012 .12 & 1.351 .61 \\
\hline 4 & 1.121 .26 & 0.880 .94 & 1.060 .62 & 0.791 .23 & 1.080 .77 & 1.271 .56 & 1.291 .61 & 1.711 .98 & 2.462 .57 & 3.585 .58 & 1.642 .50 & $2.02 \quad 1.74$ \\
\hline 5 & 1.091 .29 & 1.031 .38 & 1.121 .42 & 1.171 .21 & 0.831 .72 & 1.392 .17 & 1.431 .64 & 2.001 .96 & 2.212 .31 & 4.282 .42 & 2.112 .05 & 1.612 .37 \\
\hline 6 & 0.721 .48 & 1.160 .98 & 1.020 .68 & 1.040 .91 & 1.040 .86 & 1.231 .47 & 1.261 .52 & 2.091 .88 & 2.421 .99 & 3.393 .43 & 2.051 .64 & 2.001 .57 \\
\hline 7 & 0.911 .25 & 0.941 .08 & 1.111 .31 & 0.951 .06 & 0.891 .28 & 1.361 .15 & 1.481 .60 & 2.141 .79 & 2.172 .11 & 3.323 .89 & 1.381 .77 & 1.471 .69 \\
\hline 8 & 0.931 .11 & 1.100 .71 & 1.000 .73 & 1.031 .44 & 1.000 .68 & 1.261 .69 & 1.411 .55 & 1.662 .89 & 2.222 .31 & 3.663 .49 & 2.041 .65 & 2.031 .53 \\
\hline 9 & 1.231 .09 & 1.140 .64 & 0.811 .08 & 1.011 .52 & 1.000 .61 & 1.291 .61 & 1.341 .53 & 2.121 .99 & 2.252 .21 & 2.863 .68 & 1.691 .92 & 1.521 .66 \\
\hline 10 & 1.191 .18 & 1.551 .23 & 0.891 .67 & 1.170 .85 & 1.000 .81 & 1.261 .33 & 1.421 .8 & 2.152 .69 & 2.743 .15 & 4.224 .33 & 1.511 .66 & 1.591 .52 \\
\hline 11 & 1.822 .31 & 1.892 .09 & 1.151 .82 & 1.182 .71 & 1.212 .11 & 1.493 .01 & 1.512 .00 & 2.262 .71 & 3.096 .05 & 4.996 .25 & 2.372 .78 & 2.113 .25 \\
\hline 12 & 1.290 .85 & 1.091 .03 & 1.070 .91 & 1.011 .21 & 1.061 .33 & 1.382 .02 & 1.451 .57 & 1.421 .86 & 2.182 .39 & 3.773 .68 & 2.231 .67 & 1.391 .44 \\
\hline 13 & 1.260 .98 & 1.180 .89 & 0.791 .6 & 1.031 .00 & 1.041 .06 & 1.321 .21 & 1.471 .63 & 1.591 .99 & 2.252 .09 & 3.693 .22 & 2.002 .33 & 1.481 .72 \\
\hline 14 & 1.350 .94 & 0.991 .46 & 1.031 .05 & 0.910 .89 & 1.091 .01 & 1.271 .48 & 1.391 .61 & 1.632 .67 & 2.162 .41 & 3.553 .91 & 1.391 .75 & 1.771 .61 \\
\hline 15 & 1.181 .03 & 1.081 .89 & 1.121 .88 & 0.871 .01 & 1.040 .87 & 1.451 .28 & 1.361 .58 & 2.011 .98 & 2.913 .24 & 3.894 .06 & 1.412 .02 & 1.441 .41 \\
\hline
\end{tabular}

Table 5. Summary of mean, minimum, maximum and ESD values (mGy) for 2 age groups under study irrespective of sex.

\begin{tabular}{|c|c|c|c|c|c|}
\hline \multirow{2}{*}{$\mathrm{X}$-ray examination } & \multirow{2}{*}{ Age } & \multicolumn{4}{|c|}{ Entrance Surface dose (mGy) } \\
\hline & & Mean \pm SD & Minimum & Maximum & Ratio(Max $\backslash$ Min) \\
\hline \multirow{2}{*}{ Skull (PA) } & \multirow{2}{*}{$\begin{array}{l}10-15 \text { year } \\
\text { adult }\end{array}$} & $1.09 \pm 0.42$ & 0.51 & 1.82 & 3.56 \\
\hline & & $1.19 \pm 0.41$ & 0.52 & 2.31 & 4.44 \\
\hline \multirow{2}{*}{ Skull (lateral) } & \multirow{2}{*}{$\begin{array}{l}10-15 \text { year } \\
\text { adult }\end{array}$} & $1.08 \pm 0.38$ & 0.71 & 1.89 & 2.66 \\
\hline & & $1.16 \pm 0.40$ & 0.54 & 2.09 & 3.87 \\
\hline \multirow{2}{*}{ Cervical spine (AP) } & \multirow{2}{*}{$\begin{array}{l}10-15 \text { year } \\
\text { adult }\end{array}$} & $0.97 \pm 0.21$ & 0.65 & 1.15 & 1.76 \\
\hline & & $1.17 \pm 0.24$ & 0.49 & 1.88 & 3.83 \\
\hline \multirow{2}{*}{ Cervical spine (lateral) } & \multirow{2}{*}{$\begin{array}{c}\text { 10-15 year } \\
\text { adult }\end{array}$} & $0.99 \pm 0.30$ & 0.73 & 1.18 & 1.61 \\
\hline & & $1.20 \pm 0.27$ & 0.69 & 2.71 & 3.92 \\
\hline \multirow{2}{*}{ Chest (PA) } & \multirow{2}{*}{$\begin{array}{l}\text { 10-15 year } \\
\text { adult }\end{array}$} & $0.99 \pm 0.36$ & 0.68 & 1.21 & 1.77 \\
\hline & & $1.05 \pm 0.31$ & 0.58 & 2.11 & 3.63 \\
\hline \multirow{2}{*}{ Chest (lateral) } & \multirow{2}{*}{$\begin{array}{l}\text { 10-15 year } \\
\text { adult }\end{array}$} & $1.32 \pm 0.41$ & 1.19 & 1.49 & 1.25 \\
\hline & & $1.56 \pm 0.43$ & 1.11 & 3.01 & 2.71 \\
\hline \multirow{2}{*}{ Thoracic spine (AP) } & \multirow{2}{*}{$\begin{array}{l}10-15 \text { year } \\
\text { adult }\end{array}$} & $1.38 \pm 0.49$ & 1.23 & 1.51 & 1.22 \\
\hline & & $1.62 \pm 0.51$ & 1.50 & 2.00 & 1.33 \\
\hline \multirow{2}{*}{ Thoracic spine (lateral) } & \multirow{2}{*}{$\begin{array}{l}\text { 10-15 year } \\
\text { adult }\end{array}$} & $1.90 \pm 0.69$ & 1.56 & 2.26 & 1.44 \\
\hline & & $2.36 \pm 0.67$ & 1.79 & 2.89 & 1.61 \\
\hline \multirow{2}{*}{ Lumbar spine (AP) } & \multirow{2}{*}{$\begin{array}{l}\text { 10-15 year } \\
\text { adult }\end{array}$} & $2.32 \pm 1.21$ & 1.73 & 3.09 & 1.78 \\
\hline & & $2.59 \pm 1.27$ & 1.86 & 6.05 & 3.25 \\
\hline \multirow{2}{*}{ Lumbar spine (lateral) } & \multirow{2}{*}{$\begin{array}{l}10-15 \text { year } \\
\text { adult }\end{array}$} & $3.62 \pm 1.38$ & 2.78 & 4.99 & 1.79 \\
\hline & & $3.85 \pm 1.44$ & 2.42 & 6.25 & 2.58 \\
\hline \multirow{2}{*}{ Abdomen (AP) } & \multirow{2}{*}{$\begin{array}{l}10-15 \text { year } \\
\text { adult }\end{array}$} & $1.76 \pm 0.65$ & 1.20 & 2.37 & 1.97 \\
\hline & & $1.99 \pm 0.67$ & 1.49 & 2.78 & 1.86 \\
\hline \multirow{2}{*}{ Pelvis (AP) } & \multirow{2}{*}{$\begin{array}{l}10-15 \text { year } \\
\text { adult }\end{array}$} & $1.63 \pm 0.87$ & 1.24 & 2.11 & 1.70 \\
\hline & & $1.74 \pm 0.89$ & 1.39 & 3.25 & 2.33 \\
\hline
\end{tabular}


Table 6. ESD (mGy) values of this study compared with some international reference dose for 12 digital radiography examinations

\begin{tabular}{|c|c|c|c|c|c|c|c|c|}
\hline \multirow{2}{*}{$\begin{array}{c}\text { X-ray } \\
\text { examination }\end{array}$} & \multirow[b]{2}{*}{ Age } & \multicolumn{7}{|c|}{ Entrance Surface Dose (mGy) } \\
\hline & & This Study & $\begin{array}{c}\text { Nahangi and } \\
\text { Chaparian [19] }\end{array}$ & $\begin{array}{c}\text { Kiljunen et al. } \\
{[20]}\end{array}$ & $\begin{array}{c}\text { Osei and Darko } \\
\text { [21] }\end{array}$ & $\begin{array}{c}\text { Mohsenzadeh } \\
\text { et al. [11] }\end{array}$ & Ofori et al. [8] & $\begin{array}{c}\text { Khoshdel-Navi } \\
\text { et al. [10] }\end{array}$ \\
\hline Skull (PA) & $10-15$ & 1.09 & 3.32 & 0.12 & - & 0.94 & - & - \\
\hline \multirow{2}{*}{ Skull (lateral) } & $10-15$ & 1.08 & - & 0.53 & - & 0.82 & - & . \\
\hline & adult & 1.16 & - & - & 0.76 & 0.86 & - & 1.01 \\
\hline $\begin{array}{l}\text { Cervical spine } \\
\text { (AP) }\end{array}$ & $10-15$ & 0.97 & - & - & - & 0.44 & - & - \\
\hline \multirow{2}{*}{$\begin{array}{l}\text { Cervical spine } \\
\quad \text { (lateral) }\end{array}$} & $10-15$ & 0.99 & - & - & - & 0.52 & - & - \\
\hline & adult & 1.20 & - & - & 0.44 & 0.66 & 0.45 & 0.79 \\
\hline \multirow{2}{*}{ Chest (PA) } & $10-15$ & 0.99 & 0.21 & 0.18 & - & 0.54 & - & - \\
\hline & adult & 1.05 & 0.32 & - & 0.14 & 0.6 & 0.27 & 0.49 \\
\hline Chest (lateral) & $10-15$ & 1.32 & - & 0.47 & - & 0.71 & - & - \\
\hline $\begin{array}{l}\text { Thoracic spine } \\
\text { (lateral) }\end{array}$ & adult & 2.36 & - & - & 1.65 & 2 & - & 3 \\
\hline \multirow{2}{*}{$\begin{array}{l}\text { Lumbar spine } \\
\text { (AP) }\end{array}$} & $10-15$ & 2.32 & - & - & - & 2.14 & - & - \\
\hline & adult & 2.59 & - & - & 3.72 & 2.36 & 3.25 & 2.81 \\
\hline \multirow{2}{*}{$\begin{array}{l}\text { Lumbar spine } \\
\quad \text { (lateral) }\end{array}$} & $10-15$ & 3.62 & - & - & - & 3.37 & - & - \\
\hline & adult & 3.85 & - & - & 6.28 & 3.62 & - & 4.28 \\
\hline \multirow{2}{*}{ Abdomen (AP) } & $10-15$ & 1.76 & 2.20 & 0.63 & - & 1.53 & - & - \\
\hline & adult & 1.99 & 3.36 & - & 1.82 & 1.65 & - & 2.07 \\
\hline \multirow{2}{*}{ Pelvis (AP) } & $10-15$ & 1.63 & 2.20 & 2.54 & - & 1.35 & - & - \\
\hline & adult & 1.74 & 3.36 & - & 1.57 & 1.43 & 1.31 & 1.90 \\
\hline
\end{tabular}

Table 7. ED $(\mu \mathrm{Sv})$ values for 2 age groups under study irrespective of sex

\begin{tabular}{|c|c|c|}
\hline X-ray examination & Age & ED value $(\mu \mathrm{Sv})$ \\
\hline Skull (PA) & $\begin{array}{l}10-15 \\
\text { Adult }\end{array}$ & $\begin{array}{l}10.40 \\
13.35\end{array}$ \\
\hline Skull (Lateral) & $\begin{array}{l}10-15 \\
\text { Adult }\end{array}$ & $\begin{array}{l}18.80 \\
20.94\end{array}$ \\
\hline Cervical spine (AP) & $\begin{array}{l}10-15 \\
\text { Adult }\end{array}$ & $\begin{array}{l}33.88 \\
36.91\end{array}$ \\
\hline Cervical spine (Lateral) & $\begin{array}{l}10-15 \\
\text { Adult }\end{array}$ & $\begin{array}{l}15.04 \\
18.31\end{array}$ \\
\hline Chest (PA) & $\begin{array}{l}10-15 \\
\text { Adult }\end{array}$ & $\begin{array}{l}74.36 \\
80.87\end{array}$ \\
\hline Chest (Lateral) & $\begin{array}{l}10-15 \\
\text { Adult }\end{array}$ & $\begin{array}{l}62.22 \\
67.79\end{array}$ \\
\hline Thoracic spine(AP) & $\begin{array}{l}10-15 \\
\text { Adult }\end{array}$ & $\begin{array}{l}116.64 \\
131.45\end{array}$ \\
\hline Thoracic spine (Lateral) & $\begin{array}{l}10-15 \\
\text { Adult }\end{array}$ & $\begin{array}{l}112.53 \\
128.06\end{array}$ \\
\hline Lumbar spine (AP) & $\begin{array}{l}10-15 \\
\text { Adult }\end{array}$ & $\begin{array}{l}246.79 \\
298.02\end{array}$ \\
\hline Lumbar spine (Lateral) & $\begin{array}{l}10-15 \\
\text { Adult }\end{array}$ & $\begin{array}{l}159.68 \\
201.11\end{array}$ \\
\hline Abdomen (AP) & $\begin{array}{l}10-15 \\
\text { Adult }\end{array}$ & $\begin{array}{l}331.75 \\
378.46\end{array}$ \\
\hline Pelvis (AP) & $\begin{array}{l}10-15 \\
\text { Adult }\end{array}$ & $\begin{array}{l}177.23 \\
207.68\end{array}$ \\
\hline
\end{tabular}




\section{Discussion}

This study was the first to evaluate ED and ESD in digital radiology in Mazandaran province. In this study, ESD and the ED were evaluated in 12 common digital radiology examinations. The results of the parent study indicated a wide variation in patient's ED and ESD in the two age groups pediatrics and adults. In the mentioned 12 examinations, ESD and ED increase with age. It can be suggested that these variations are a result of radiation conditions of the examinations, quality control of the x-ray machines, FFD, methods of radiography, and types of equipment.

The highest ESD was related to the lumbar spine (lateral) examination and the least to the skull (lateral) examination. Means of patient's ESD ranged from $0.97 \mathrm{mGy}$ for cervical spine (AP) in the 10-15 year group to $3.85 \mathrm{mGy}$ for lumbar spine (lateral) in the adults. High levels of ESD in the lateral view are attributed to the increase in the thickness of the examined organ relative to the other view. This results in the increase in the radiation condition. The mean ESD values chest (PA) obtained in this study was $1.05 \mathrm{mGy}$ for adults, that is higher than other studies, for example, the study of Mohsenzadeh and Nahangi $\mathrm{H}$ et al their mean ESD values chest (PA) for adults are 0.61 and 0.32 , respectively.

Table 7 shows the lowest ED for the 10-15 year range in skull (PA) examination is $10.40(\mu \mathrm{Sv})$ and the highest $\mathrm{ED}$ for adults in the abdominal (AP) examination is $378.46(\mu \mathrm{Sv})$. The results of this study show that the ED values for the two age groups of 10-15 years and adults in the abdomen (AP), pelvis (AP), and lumbar spine (AP) techniques were respectively higher than the other techniques. The reason for the high ED value in these three radiographic examinations is firstly due to the high X-ray examination parameters and then a large number of sensitive organs in the radiation field of these techniques. In both techniques, namely the lumbar spine (AP) and abdomen, most of the internal organs are irradiated. Since the most effective factors on the amount of ESD and ED in digital radiology examination are field size, $\mathrm{kVp}$ difference, FFD, etc, best practice protocols can be used to reduce the effective contribution [15].

In the case of FDD, these values varied in different centers and varied on average from $90 \mathrm{~cm}$ to $180 \mathrm{~cm}$. This survey reveals a significant variation in radiological practice including. Ostensibly, the X-ray examination parameters which are set by radiologic technicians could change in a wider range, for example, in adults, the mAs vary from $10 \mathrm{mAs}$ to $21 \mathrm{mAs}$ for chest (PA) examinations, and from $17 \mathrm{mAs}$ to $40 \mathrm{mAs}$ for abdomen examinations.
Khoshdel et. al. [10] reported that the minimum and maximum ESD were $0.49 \mathrm{mGy}$, and $4.28 \mathrm{mGy}$ for chest (PA) and lumbar (lateral), respectively [10]. In this study, the minimum and maximum ESD were found to be $0.97 \mathrm{mGy}$ and $3.85 \mathrm{mGy}$ in the cervical (AP) and lumbar (lateral), respectively. As can be seen, the values are not much different.

In the study by Balonov [16] published on the ED and risks of X-rays it was stated that the highest ED was related to the abdomen (AP) and lumbar (AP) techniques and th(e lowest was related to the skull (AP) [16]. These results are similar to our study. The abdomen (AP) is used because it has the most sensitive organs and also a larger field. And in the lumbar (AP), ED increases due to the high $\mathrm{kVp}$ and $\mathrm{mAs}$.

Studies of Sulieman et al. [17] and Kutanzi et al [18] were conducted on the ED and radiation effects on children and have shown that the sensitivity to the radiation in childhood is $2-3$ times higher than the adults. In consistence with these results, this study indicates that the age group of 10-15 years is more sensitive than the adults due to the high cell division and longer life span $[17,18]$.

The results of this study are limited to Mazandaran province and cannot be generalized to the whole country.

\section{Conclusion}

According to the results obtained in this study, it can be concluded that the ED and ESD differences are due to the application of the procedures (such as $\mathrm{kVp}$ and $\mathrm{mAs}$, radiologist skills, field, etc.). Therefore, considering the importance of radiation conditions on patient ED and ESD and image quality, these conditions can be chosen to reduce the patient ED and ESD as much as possible while maintaining image quality.

General, low $\mathrm{kVp}$ and high $\mathrm{mAs}$ techniques may have increased the dose. More extensive studies on the parameters affecting the dose as well as the introduction of more advanced devices can greatly reduce the patient ESD and radiation risk. Implementation of a QA program, relying on detector quality and inspection of other radiographic devices, can be a reasonable step in reducing patient dose. In addition, a medical physicist is recommended to achieve these goals in medical centers.

\section{Acknowledgment}

The authors would like to send their best appreciations to the Vice Chancellor of Research of Babol University of Medical Sciences (Babol, Iran) for financial support (Grant No. 5149). 


\section{References}

[1] Bair W. Overview of ICRP respiratory tract model. Radiation Protection Dosimetry. 1991;38(1-3):147-152.

[2] Hall EJ, Brenner DJ. Cancer risks from diagnostic radiology. Br J Radiol. 2008;81(965):362-378.

[3] Giczi F, Pellet S, Mclean I D, Meghzifene A. Testing of the implementation of the code of practice on dosimetry in X-ray diagnostic radiology: Hungarian contribution. 2008. IRPA 12: 12. International congress of the International Radiation Protection Association (IRPA): Strengthening radiation protection worldwide, Buenos Aires (Argentina), 19-24 Oct 2008

[4] Ross BC, Dixon DW. Exposure to radon in above ground workplaces the experience in great britain (GB). In: 8 . International congress of the International Radiation Protection Association (IRPA8). 1992.

[5] Pahade JK, Trout AT, Zhang B, et al. What patients want to know about imaging examinations: a multiinstitutional us survey in adult and pediatric teaching hospitals on patient preferences for receiving information before radiologic examinations. Radiology. 2018;287(2):554-562.

[6] Beir VII, Health risks from exposure to low levels of ionizing radiation. The National Academies report in brief, National Academies Press (NAP); 2005.

[7] Mettler F, Radiological risks associated with the various uses of radiation in medicine within the context of their associated benefits. In: Radiological Protection of Patients in Diagnostic and Interventional Radiology, Nuclear Medicine and Radiotherapy (NMR); Proceedings of an international conference held in Málaga,Spain, 26-30 March 2001. p. 119-127.

[8] Ofori K, Gordon SW, Akrobortu E, et al. Estimation of adult patient doses for selected X-ray diagnostic examinations. Journal of Radiation Research and Applied Sciences. 2014;7(4):459-462.

[9] Ciraj O, Markovic S, Kosutic D. First results on patient dose measurements from conventional diagnostic radiology procedures in Serbia and Montenegro. Radiation Protection Dosimetry. 2005;113(3):330-335.

[10] Khoshdel-Navi D, Shabestani-Monfared A, Deevband MR, et al. Local-Reference patient dose evaluation in conventional radiography examinations in Mazandaran, Iran. Journal of Biomedical Physics \& Engineering. 2016;6(2):61-70.

[11] Mohsenzadeh B, Deevband MR, Pouriran R. The national diagnostic Reference Level in Routine Digital Radiography Examinations in Iran. Biomedical Journal. 2016;7(5):6183-6192.

[12] Zoetelief J, Dance DR, Drexler G, et al. Patient dosimetry for X-rays used in medical imaging. J ICRU. 2005;5(2):1-113.

[13] AlSuwaidi JS, AIMazrouei NK, Pottybindu S. Patient dose monitoring in Dubai in radiography and interventional procedures. Annals of the ICRP. 2015;44(1 Suppl):249-258.

[14] Vano , Fernandez JM, Ten JI, et al. Transition from screen-film to digital radiography: evolution of patient radiation doses at projection radiography. Radiology. 2007;243(2):461-466.

[15] Karami V, Zabihzadeh M, Shams N, et al. Optimization of Radiological Protection in Pediatric Patients Undergoing Common Conventional Radiological Procedures: Effectiveness of Increasing the Film to Focus Distance (FFD). International Journal of Pediatrics. 2017;5(4):4771-4782.

[16] Balonov MI, Shrimpton PC. Effective dose and risks from medical x-ray procedures. Annals of the ICRP. 2012;41(3-4):129-141.

[17] Sulieman A, Elhag B, Alkhorayef M, et al. Estimation of effective dose and radiation risk in pediatric barium studies procedures. Applied Radiation and Isotopes. 2018;138:40-44.

[18] Kutanzi K, Lumen A, Koturbash I, Miousse IR. Pediatric exposures to ionizing radiation: carcinogenic considerations. International Journal of Environmental Research and Public Health. 2016;13(11):1057.

[19] Nahangi H, Chaparian A. Assessment of radiation risk to pediatric patients undergoing conventional X-ray examinations. Radioprotection. 2015;50(1):19-25.

[20] Kiljunen T, Tietavainen A, Parvainen T, et al. Organ doses and effective doses in pediatric radiography: patient-dose survey in Finland. Acta Radiologica. 2009;50(1):114-124.

[21] Osei EK , Darko J. A survey of organ equivalent and effective doses from diagnostic radiology procedures. ISRN Radiology. 2012;2013:204346. 